\title{
Effects of Sorghum Silage in Lactating Buffalo Cow Diet: Biochemical Profile, Milk Yield, and Quality
}

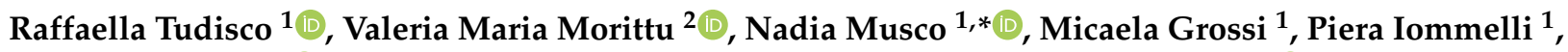 \\ Biagio D'Aniello $^{3}$ (D), Maria Ferrara ${ }^{1}$, Federico Infascelli ${ }^{1,+}$ and Pietro Lombardi ${ }^{1,+}$ (I) \\ 1 Department of Veterinary Medicine and Animal Production, University of Napoli Federico II, \\ 80100 Napoli, Italy; tudisco@unina.it (R.T.); micaelagrossi@tiscali.it (M.G.); pieraiommelli@gmail.com (P.I.); \\ maferrar@unina.it (M.F.); federico.infascelli@unina.it (F.I.); pietro.lombardi@unina.it (P.L.) \\ 2 Department of Health Sciences, Magna Graecia University of Catanzaro, 88100 Catanzaro, Italy; \\ morittu@unicz.it \\ 3 Department of Biology, University of Naples Federico II, 80126 Naples, Italy; biagio.daniello@unina.it \\ * Correspondence: nadia.musco@unina.it \\ + These authors contributed equally to this work.
}

check for updates

Citation: Tudisco, R.; Morittu, V.M.; Musco, N.; Grossi, M.; Iommelli, P.; D'Aniello, B.; Ferrara, M.; Infascelli, F.; Lombardi, P. Effects of Sorghum Silage in Lactating Buffalo Cow Diet: Biochemical Profile, Milk Yield, and Quality. Agriculture 2021, 11, 57. https://doi.org/10.3390/ agriculture11010057

Received: 24 November 2020 Accepted: 8 January 2021 Published: 12 January 2021

Publisher's Note: MDPI stays neutral with regard to jurisdictional clai$\mathrm{ms}$ in published maps and institutional affiliations.

Copyright: (C) 2021 by the authors. Licensee MDPI, Basel, Switzerland. This article is an open access article distributed under the terms and conditions of the Creative Commons Attribution (CC BY) license (https:// creativecommons.org/licenses/by/ $4.0 /)$.

\begin{abstract}
The influence of replacing silage with sorghum silage in the diet of dairy buffalo cows on metabolic status and on milk yield, chemical characteristics, and fatty acid profile was studied. Forty dairy buffalo cows were included in the trial and divided into two homogeneous groups (SS, sorghum silage and CS, corn silage). Blood was collected at the end of the trial (120 days), individual milk yield was registered daily. Samples of milk were monthly collected and analyzed for fat, protein, and lactose. Moreover, fatty acid profiles of silages and milk were determined. Buffalo cows fed sorghum silage showed an average milk yield higher than group CS (kg/d 10.120 vs. 9.270; $p<0.05)$, probably due to the lower lignin content of sorghum silage $(31.0 \mathrm{~g} / \mathrm{kg}$ dry matter (DM)) compared to corn silage $(47.0 \mathrm{~g} / \mathrm{kg} \mathrm{DM})$ and, by consequence, to the higher digestibility of SS diet. The percentage of linoleic acid was significantly higher in milk of group CS (C18:2: 1.27 vs. $2.05 \% ; p<0.01)$ due to the higher content of these acids in corn than in sorghum silage. The omega 6/omega 3 ratio was significantly lower in milk from buffalo cows fed sorghum than those fed corn silage (7.8 vs. 12.9; $p<0.01)$. Serum biochemistry showed no negative effects of the corn replacing with sorghum.
\end{abstract}

Keywords: sorghum silage; corn silage; buffalo cows; milk; serum biochemistry

\section{Introduction}

The breeding of Bufala Mediterranea Italiana (Bubalus bubalis) represents an important sector for the Italian economy, in particular to produce mozzarella cheese with a growing trend that has reached 426 million euros in 2019 [1].

Corn silage (Zea mays L.) is the main forage used in the diets of dairy buffaloes, but several concerns related to its use have been raised in recent years. In particular, the cost of irrigation represents a limit to corn cultivation. Furthermore, corn presents a contamination risk by mycotoxins, produced by fungal organisms. In particular, the genera Fusarium $(47 \%)$, Aspergillus (34\%) can be found in the corn silage. The molds of the genus Fusarium can produce 20 different mycotoxins, including zearalenone and fumonisin, while molds of the Aspergillus genus produce aflatoxins [2]. Indeed, the effects of micotoxins counteracted with feed additives.

These concerns have given growing interest to the possible substitution of corn silage with other silages, such as sorghum silage (Sorghum vulgare L.). Sorghum can tolerate drought better than corn and it can be attributed to the root system, characterized by primary roots able to provide water and nutrients from the soil, and secondary roots finer and branched approximately more than double as roots from corn plants, able to penetrate very deep into the soil. In addition, leaves represent a small area per plant, and 
this can limit the transpiration, thus, in dry and warm conditions sorghum can bend more efficiently compared to corn [3]. For all these reasons, and since sorghum was showed to make silage nearly equal to corn silage [4], several authors investigated about its possible use in ruminant diet and, in particular, about the effects of a partial or total replacement of corn silage.

Moreover, as consumer requirements concerning food quality have largely improved in recent years and since animal diet has been widely demonstrated to affect food nutritional characteristics, research must also investigate this aspect, assessing any possible change of food nutritional value occurring by modifying animal diet ingredients. As suggested by Cattani et al. [2] in dairy cows this is particularly important when dealing with the fatty acid profile, mainly the concentration of omega-3 polyunsaturated fatty acids, which have been associated with a decrease in the risk of heart disease and with conjugated linoleic acids (CLA) which are recognized as having antioxidative and anticarcinogenic properties in animal models [5,6] and in human [7]. Aim of present trial was to study the influence of replacing corn silage with sorghum silage in the diet of dairy buffalo cows bred in South Italy, on animal health and milk yield, chemical characteristics, and fatty acid profile.

\section{Materials and Methods}

\subsection{Animals and Diets}

The trial was performed according to the Animal Welfare and Good Clinical Practice (Directive 2010/63/EU) and was approved by the local Bioethics Committee (protocol number: PG/0016571). The trial was carried out at a dairy buffalo farm in Cassino, province of Frosinone (Frosinone, Italy), located on an irrigated area $\left(41^{\circ} 26^{\prime} 27^{\prime \prime} \mathrm{N}, 13^{\circ} 50^{\prime} 00^{\prime \prime} \mathrm{E}\right.$, $40 \mathrm{~m}$ a.s.l.) with $1100 \mathrm{~mm}$ average annual rainfall mainly concentrated in autumn-winter and monthly average temperatures ranging from $7.3^{\circ} \mathrm{C}$ (January) to $23.3^{\circ} \mathrm{C}$ (August). The farm host 150 Italian Mediterranean buffalo cows in open yards that allowed $15 \mathrm{~m}^{2}$ with a feeding trough space of around $1.0 \mathrm{~m}^{2} /$ head. For the sorghum (Sorghum vulgare L.) the forage hybrid seeds BMR 333 (Brown Mid Rib) and for the corn (Zea mais L.), as farm use, the cultivar Kamil (class FAO 400) were used. Both the forages were sown in a soil that previously hosted alfalfa (Medicago sativa L.), fertilized with bibasic ammonia phosphate ( 2 quintal/ha) plus urea ( $2 \mathrm{q} / \mathrm{ha}$ ) at sowing time, and ammonia nitrate ( $2 \mathrm{q} / \mathrm{ha})$ at covering, for a total nitrogen of $150 \mathrm{~kg} / \mathrm{hectare}$. Eight irrigations $\left(5000 \mathrm{~m}^{3} / \mathrm{ha}\right)$ for the corn and one for the sorghum was affected. The crops, seeded in May 2017, were harvested in September (soft dough and kernel dent phases of maturity, for sorghum and corn respectively) chopped and ensiled in two bunker silos for about $40 \mathrm{~d}$. After silos opening, 3 representative samples of each forage were monthly taken, pooled, and analyzed for fermentation parameters, according to Calabrò et al. [8]. Other 3 representative samples of each forage were monthly taken, pooled and dried at $60^{\circ} \mathrm{C}$ for $48 \mathrm{~h}$. Both forages and concentrate ( 3 representative samples) were milled $(1.1 \mathrm{~mm}$ screen) and were analyzed for the chemical composition [9]. In particular, Crude Protein (CP), Ether Extract (EE) and Ash were determined, and the moisture and carbohydrate content can then be calculated by difference: Carbohydrates $=$ amount of total sample-moisture-Crude Protein-Ether Extract.

In addition, the fibrous carbohydrates were fractioned according to Van Soest et al. [10]. Van Soest method is a system of analysis which gives a better characterization of fiber content. In a first step, the sample is treated with a neutral detergent solution (NDS) with a heat-stable amylase to make the sugars, starches, and pectin. The remaining residue consists of the non or less-digestible cell wall substances hemicellulose, cellulose, and lignin. In a second step, hemicellulose is made soluble using an acid detergent solvent (ADS). The residue, consisting of cellulose and lignin is then treated with concentrated sulfuric acid, dissolving the cellulose and leaving the lignin in the residue. These steps can be performed consecutively or separately to determine: Neutral Detergent Fiber (NDF), Acid Detergent Fiber (ADF) and Acid Detergent Lignin (ADL). 
Net energy for lactation (NEl, MJ/kg dry matter (DM)) content was estimated as suggested by Sauvant and Nozière [11]. Samples of alfalfa hay and concentrate were analyzed as well.

For the analysis of fatty acids, the method proposed by Folch et al. [12] and modified for plant foods was used. In brief, $20 \mathrm{~g}$ of finely chopped sample with $300 \mathrm{~mL}$ of a chloroform/methanol mixture (2:1) were put in a bottle, shaken for $5 \mathrm{~min}$ and left to macerate overnight. After a 40 Wathman filtering, $0.88 \% \mathrm{KCl}(1 / 5$ of the volume) of the filtrate were added to the filtrate in a separate funnel, shaken for $1 \mathrm{~min}$ and allowed to separate. The lower phase (chloroform + lipids) was collected and added to a mixture of methanol and water (1:1) equal to $\frac{1}{4}$ of the volume collected from the first separation. After 1 min shaking and a new separation in two phases, the lower phase was put in a flask and evaporate the chloroform with a Rotavapor. The extract was then collected with hexane and transferred into vials until subsequent methylation.

Immediately after calving, 40 multiparous dairy buffalo cows (live weight: $\mathrm{kg} 650 \pm 13$ ) were equally divided into two homogeneous groups (SS and CS) based on parity (3 to 5 calving) and previous milk yield ( $\mathrm{kg} 2180 \pm 142$ in 270 days). They were allocated in ten separate open yards ( 5 per group; 4 animals/each) that allowed $15 \mathrm{~m}^{2}$ with a feeding trough space of around $1.0 \mathrm{~m} /$ head and with free access to water. To meet their nutritive requirements, two isoenergy and isoprotein diets (Table 1) were formulated using alfalfa hay, concentrate and sorghum (diet SS) or corn silage (diet CS) and administered, once daily, as total mixed ration (TMR), prepared by a total mixer wagon. The amount of TMR distributed in the mangers of each group as well as orts were measured daily.

Table 1. Diets ingredients ( $\mathrm{kg}$ of dry matter (DM)), crude protein $(\mathrm{g} / \mathrm{kg} \mathrm{DM})$ and energy (NEl, $\mathrm{MJ} / \mathrm{kg}$ DM).

\begin{tabular}{ccc}
\hline Ingredients & SS & CS \\
\hline Corn silage & - & 5.325 \\
Sorghum silage & 5.000 & - \\
Alfalfa hay & 3.670 & 3.450 \\
Concentrate * & 6.500 & 6.225 \\
Crude protein & 152.0 & 150.0 \\
NEl, MJ/kg DM & 6.335 & 6.335 \\
\hline
\end{tabular}

SS, sorghum silage diet; $\mathrm{CS}$, corn silage diet; $\mathrm{Nel}$, net energy for lactation; ${ }^{*}$ Concentrate ingredients (\% DM): wheat bran 33.0, fava bean 30.0, pea seeds 12.0, cotton meal 8.8, corn meal 7.5, dried beet pulp 6.0, CaCO3 1.6, vit-min 1.1.

\subsection{Milk Analyses}

Individual milk yield was daily registered and monthly (from 30 days until 120 days in milk) samples, representative of the two daily milkings, were collected and analyzed for fat, protein, and lactose (MilkoScan ${ }^{\mathrm{TM}}$ 133B, Foss Electric, Hilleroed, Denmark). Moreover, milk and silages fatty acid profiles were determined. Fat from silages were extracted by a chloroform/methanol solution (2:1) as reported by Folch et al. [12], while milk lipids were extracted using the method described by Hara and Radin [13]. In both cases, extracted lipids were evaporated in a stream of nitrogen, then recovered with $5 \mathrm{~mL}$ of hexane and stored in amber glass vials with screw caps at a temperature of $-20{ }^{\circ} \mathrm{C}$ until the subsequent derivatization operation. The samples extracted were esterified by treating a volume of extract containing $75 \mathrm{mg}$ of fat with $500 \mu \mathrm{L}$ of saturated solution of potassium hydroxide in methanol in teflon-coated screw cap tubes for $20 \mathrm{~min}$ at room temperature in according to Basic transmethylation: IDF-FIL method 182 . The tubes were centrifuged $(2000 \times g)$ for $10 \mathrm{~min}$ and the volume of the upper phase containing the methyl esters of fatty acids (FAME) was removed and analyzed on the same day. The FAMEs were analyzed in a Gaschromatograph model FOCUS (Thermo Scientific Co. Waltham, MA, USA, 02451) equipped with a capillary column in fused silica $\mathrm{SP}^{\circledR}-2380(100 \mathrm{~m}$ length $\times 0.25 \mathrm{~mm}$ inner diameter $\times 0.20 \mu \mathrm{m}$ film thickness (Supelco, Inc, Bellefonte, PA, USA) using the AS $3000 \mathrm{II}$ autosampler. The carrier gas, helium, was set at the constant pressure of $180 \mathrm{kPa}$, 
splitting flow of $50 \mathrm{~mL} / \mathrm{min}$, injection volume of $1 \mu \mathrm{L}$. Column parameters: the initial temperature of the column was maintained at $170{ }^{\circ} \mathrm{C}$ for $15 \mathrm{~min}$; then with an increase of $5{ }^{\circ} \mathrm{C} / \mathrm{min}$ it was brought up to $240{ }^{\circ} \mathrm{C}$. The total execution time was $64 \mathrm{~min}$. The data were collected automatically, using the Chrom-Card for Windows program (Thermo Scientific Co. Waltham, MA, USA, 02451), the fatty acids were identified by comparing the retention times of the commercial standards containing 37 methyl esters of fatty acids (Sigma Aldrich, Inc., St. Louis, MO, USA, 63103). The retention times of the CLA isomers were controlled by the elution of commercial standards (Larodan AB-SE-171 65 Solna Sweden) of these fatty acids. The area of each individual fatty acid identified in the sample was quantified by percentage calculation on the total area of the eluted peaks, as described by Tudisco et al. [14].

\subsection{Blood Analyses}

The same veterinary practitioner monthly examined animals to assess their health status. At 120 days blood was withdrawn from the coccygeal vein before the morning feeding. Samples were collected into $10 \mathrm{~mL}$ vacutainer tubes (Becton Dickinson, Franklin Lakes, NJ, USA) and allowed to clot and kept at $4{ }^{\circ} \mathrm{C}$ until separation of serum. Clotted blood was centrifuged at $1600 \times g$ at $4{ }^{\circ} \mathrm{C}$ for $20 \mathrm{~min}$. The separated serum samples were stored at $-80^{\circ} \mathrm{C}$ until analysis to avoid loss of bioactivity and contamination and were thawed on ice for approximately $2 \mathrm{~h}$ before use. Analyses were made using an automatic biochemical analyzer AMS Autolab (Analyzer Medical System, Rome, Italy) by the following reagents from Spinreact (Girona, Spain): blood urea nitrogen (BUN), creatinine (CREA), glucose (GLU), aspartate amino transferase (AST), cholesterol (CHO) and triglycerides (TRI). $\beta$-hydroxybutyric acid (B-HBA) and non-esterified fatty acids (NEFA) were assayed by using kits from Catachem (Bridgeport, CT, USA) and Randox (Crumlin, County Antrim, Ireland, UK), respectively. Reagents from Diacron International s.r.l. (Grosseto, Italy) were used to determine reactive oxygen metabolites (d-ROMs) and the biological antioxidant potential (BAP).

\subsection{Statistical Analysis}

Data of milk yield and quality were analyzed using the JMP ${ }^{\circledR}$ (Version 9 SW, SAS Institute Inc., Cary, NC, USA, 1989-2019), according to the model:

$$
y i j k=m+G i+P j+G \times P i j+e i j k
$$

where yijk = single observation; $\mathrm{m}=$ mean; $\mathrm{Gi}=$ group effect $(\mathrm{i}=\mathrm{C}$ and $\mathrm{S}) ; \mathrm{Mj}=$ month of milking effect $(j=I, \ldots I V) ; G i \times M j=$ interaction group $\times$ month; eijk = error. The differences among means were tested by Tukey test and the differences were considered statistically significant at $p<0.05$.

Data of blood samples were analyzed with one-way ANOVA using the JMP ${ }^{\circledR}($ Version 9 SW, SAS Institute Inc., Cary, NC, USA, 1989-2019) considering only the group effect according to the following model:

$$
y i j=m+G i+e i j
$$

where $y \mathrm{ij}=$ single observation; $\mathrm{m}=$ general mean; $\mathrm{Gi}=$ group effect $(\mathrm{i}=\mathrm{CS}$ and SS); eij $=$ error. The differences among means were tested by Tukey test and the differences were considered statistically significant at $p<0.05$.

\section{Results}

\subsection{Silages}

Sorghum silage (SS) showed lower DM (26.2 vs. $28.5 \%)$ and protein content (CP: 80.2 vs. $83.0 \mathrm{~g} / \mathrm{kg} \mathrm{DM}$ ) than CS. Concerning fibrous fractions, NDF were slightly higher in sorghum silage while ADL in corn silage (569.3 vs. $551.2 \mathrm{~g} / \mathrm{kg}$ DM and 31.0 vs. $47.0 \mathrm{~g} / \mathrm{kg}$, for SS and CS, respectively). In addition, the ADL/NDF ratio was different between diets 
(8.53 vs. 5.44 for CS and SS, respectively), thus suggesting that the lignification of the cell wall occurred differently between the two diets.

The net energy for lactation of silages were similar ( 5.125 vs. $5.267 \mathrm{MJ} / \mathrm{kg} \mathrm{DM}$, for sorghum and corn silage, respectively) (Table 2).

Table 2. Feeds chemical composition (g/kg DM) and nutritive value.

\begin{tabular}{ccccc}
\hline Chemical Characteristics & Sorghum Silage & Corn Silage & Alfalfa Hay & Concentrate * \\
\hline DM (\%) & $26.2 \pm 0.4$ & $28.5 \pm 0.3$ & - & - \\
Crude protein & $80.2 \pm 1.3$ & $83.0 \pm 1.6$ & $161.0 \pm 1.6$ & 203.0 \\
Ether extract & $32.2 \pm 0.7$ & $33.0 \pm 0.6$ & $20.0 \pm 0.4$ & 55.1 \\
NDF & $569.3 \pm 32.2$ & $551.2 \pm 34.1$ & $439.0 \pm 15.7$ & 232.4 \\
ADF & $360.1 \pm 19.8$ & $361.3 \pm 21.6$ & $313.0 \pm 10.8$ & 92.3 \\
ADL & $31.0 \pm 0.9$ & $47.0 \pm 1.1$ & $52.0 \pm 0.8$ & 24.2 \\
NEl MJ/kg DM & $5.125 \pm 0.3$ & $5.267 \pm 0.2$ & $5.480 \pm 0.2$ & 7.829 \\
\hline
\end{tabular}

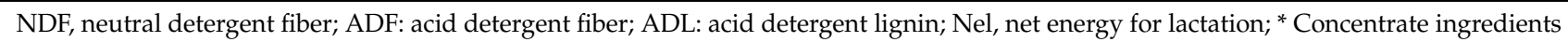
(\% DM): wheat bran 33.0, fava bean 30.0, pea seeds 12.0, cotton meal 8.8, corn meal 7.5, dried beet pulp 6.0, CaCO3 1.6, vit-min 1.1.

The fermentations were adequate for both the silages (Table 3) as suggested by $\mathrm{pH}$ values, negligible proportion of propionic and butyric acids, much higher production of lactic than acetic acid and $\mathrm{N}-\mathrm{NH}_{3}$ values lower than $7 \mathrm{~g} / \mathrm{kg}$ total $\mathrm{N}$ [15].

Concerning silages fatty acid profile, the percentage of stearic (C18:0) and myristic acid (C14:0) were similar between the silages. Corn silage showed higher content of linoleic acid (C18:2: 21.0 vs. $35.8 \%$, for SS and CS silage respectively) and sorghum silage higher contents of palmitic (C:16: 20.80 vs. $17.0 \%$, for SS and CS silage, respectively) oleic (C18:1: 26.6 vs. $24.4 \%$, for SS and CS silage respectively) and alfa-linolenic acid (C18:3: 13.6 vs. $5.8 \%$, for SS and CS silage respectively). Sorghum silage showed higher proportion of arachidonic acid and behenic acids (C20:0: 1.31 vs. $0.40 \%$ and C22:0: 0.98 vs. $0.42 \%$, for SS and CS respectively) compared to corn silage.

Table 3. Silages fermentative parameters and fatty acids profile ( $\%$ total FA).

\begin{tabular}{|c|c|c|}
\hline Fermentative Parameters & Sorghum Silage & Corn Silage \\
\hline $\mathrm{pH}$ & $4.15 \pm 0.2$ & $4.03 \pm 0.3$ \\
\hline Lactic acid (g/kg DM) & $42.3 \pm 1.6$ & $46.0 \pm 1.9$ \\
\hline Acetic acid (g/kg DM) & $13.1 \pm 0.5$ & $15.0 \pm 0.3$ \\
\hline Propionic acid (g/kg DM) & $0.5 \pm 0.01$ & $0.5 \pm 0.02$ \\
\hline Butyric acid (g/kg DM) & $0.3 \pm 0.002$ & $0.2 \pm 0.002$ \\
\hline $\mathrm{N}-\mathrm{NH}_{3}(\mathrm{~g} / \mathrm{kg}$ total $\mathrm{N})$ & $4.20 \pm 0.4$ & $5.30 \pm 0.3$ \\
\hline \multicolumn{3}{|l|}{ Fatty acid profile } \\
\hline C14:0 & $0.40 \pm 0.03$ & $0.30 \pm 0.03$ \\
\hline C14:1 & $0.02 \pm 0.001$ & $0.02 \pm 0.002$ \\
\hline C16:0 & $20.8 \pm 2.01$ & $17.0 \pm 2.13$ \\
\hline C16:1 & $0.31 \pm 0.02$ & $0.20 \pm 0.03$ \\
\hline C18:0 & $2.4 \pm 0.03$ & $2.3 \pm 0.03$ \\
\hline $\mathrm{C} 18: 1$ cis 9 & $26.6 \pm 0.9$ & $24.4 \pm 0.8$ \\
\hline C18:1 cis 11 & $1.12 \pm 0.02$ & $0.81 \pm 0.02$ \\
\hline $\mathrm{C} 18: 2$ cis 9 cis 12 & $21.0 \pm 0.8$ & $35.8 \pm 1.2$ \\
\hline $\mathrm{C} 18: 3$ cis 9 cis 12 , cis 15 & $13.6 \pm 1.10$ & $5.8 \pm 0.5$ \\
\hline C20:0 & $1.31 \pm 0.1$ & $0.4 \pm 0.06$ \\
\hline C20:1 cis 11 & $0.3 \pm 0.01$ & $0.2 \pm 0.01$ \\
\hline C20:2 & $0.02 \pm 0.01$ & $0.02 \pm 0.01$ \\
\hline C22:0 & $0.98 \pm 0.01$ & $0.42 \pm 0.01$ \\
\hline C24:0 & $1.02 \pm 0.04$ & $0.72 \pm 0.03$ \\
\hline
\end{tabular}

SS, sorghum silage; CS, corn silage. 


\subsection{Milk}

No refusals were detected for both groups; dry matter intake (DMI) was similar between the groups (Table 4). Buffalo cows fed sorghum silage showed an average milk yield significantly higher than group CS $(\mathrm{kg} / \mathrm{d} 10.120$ vs. 9.270; $p<0.05)$ and the differences were observed also for the sampling effect, as well as the interaction between group and sampling. Milk chemical composition was not significantly different between the treatments.

Table 4. Daily dry matter intake (DMI, kg DM/head/day), milk yield (kg/head/day) and chemical composition (\%).

\begin{tabular}{|c|c|c|c|c|c|c|}
\hline Milk Chemical Composition & SS & CS & $\begin{array}{l}\text { Group } \\
\text { Effect }\end{array}$ & $\begin{array}{c}\text { Sampling } \\
\text { Effect }\end{array}$ & $\mathbf{G} \times \mathbf{S}$ & SEM \\
\hline DMI & 15.17 & 15.00 & NS & NS & NS & 2.1 \\
\hline Yield & 10.120 & 9.270 & * & $*$ & $*$ & 1.5 \\
\hline Fat & 8.52 & 8.38 & NS & NS & NS & 0.21 \\
\hline Protein & 4.70 & 4.68 & NS & NS & NS & 0.16 \\
\hline Lactose & 5.01 & 5.02 & NS & NS & NS & 0.12 \\
\hline
\end{tabular}

SS, sorghum silage; CS, corn silage; DMI: dry matter intake; ${ }^{*}, p<0.05$; NS, Not Significant; SEM, standard error of mean.

Most of milk fatty acids were unaffected by treatment (Table 5), even if group CS showed significantly $(p<0.01)$ higher percentage of linoleic acid (C18:2 cis9cis12: $2.05 \mathrm{vs.}$ $1.27 \%$ ), total PUFA ( 3.2 vs. $2.32 \%$ ) and PUFA omega 6 (2.45 vs. $1.56 \%$ ) compared to SS group. The omega 6/omega 3 ratio was significantly lower in milk from SS than CS group (7.8 vs. $12.9 ; p<0.01)$.

Table 5. Milk fatty acid profile (\% total fatty acids).

\begin{tabular}{|c|c|c|c|c|c|c|}
\hline Milk Fatty Acids Profile & SS & CS & Group Effect & $\begin{array}{c}\text { Sampling } \\
\text { Effect }\end{array}$ & $\mathbf{G} \times \mathbf{S}$ & SEM \\
\hline C4:0 & 4.00 & 3.72 & NS & NS & NS & 0.97 \\
\hline C6:0 & 1.80 & 1.77 & NS & NS & NS & 0.38 \\
\hline C8:0 & 0.88 & 0.89 & NS & NS & NS & 0.20 \\
\hline C10:0 & 1.92 & 1.98 & NS & NS & NS & 0.56 \\
\hline C11:0 & 0.14 & 0.15 & NS & NS & NS & 0.02 \\
\hline $\mathrm{C} 12: 0$ & 2.67 & 2.65 & NS & NS & NS & 0.53 \\
\hline $\mathrm{C} 14: 0$ & 11.0 & 11.1 & NS & NS & NS & 1.53 \\
\hline C14:1 cis 9 & 0.24 & 0.28 & NS & NS & NS & 0.05 \\
\hline $\mathrm{C} 15: 0$ & 0.78 & 0.74 & NS & NS & NS & 0.03 \\
\hline $\mathrm{C} 15: 1$ & 0.18 & 0.17 & NS & NS & NS & 0.01 \\
\hline $\mathrm{C} 16: 0$ & 31.40 & 32.00 & NS & NS & NS & 2.84 \\
\hline C16:1 cis 9 & 1.42 & 1.43 & NS & NS & NS & 0.20 \\
\hline C17:0 & 0.74 & 0.75 & NS & NS & NS & 0.05 \\
\hline $\mathrm{C} 17: 1$ & 0.27 & 0.25 & NS & NS & NS & 0.02 \\
\hline C18:0 & 13.20 & 13.33 & NS & NS & NS & 0.62 \\
\hline $\mathrm{C} 18: 1$ cis 9 & 3.09 & 3.08 & NS & NS & NS & 0.53 \\
\hline C18:1 trans 11 & 21.15 & 21.95 & NS & NS & NS & 0.90 \\
\hline C18:2 trans 9 trans 12 omega 6 & 0.15 & 0.24 & NS & NS & NS & 0.11 \\
\hline C18:2 cis 9 cis 12 omega 6 & 1.27 & 2.05 & $* *$ & $* *$ & $* *$ & 0.87 \\
\hline C20:0 & 0.50 & 0.48 & NS & NS & NS & 0.04 \\
\hline C18:3 omega 3 & 0.20 & 0.19 & NS & NS & NS & 0.09 \\
\hline $\mathrm{C} 22: 0$ & 0.21 & 0.24 & NS & NS & NS & 0.14 \\
\hline C24:0 & 0.22 & 0.19 & NS & NS & NS & 0.04 \\
\hline C22:6 omega 6 & 0.14 & 0.16 & NS & NS & NS & 0.02 \\
\hline CLA cis 9 trans 11 & 0.50 & 0.53 & NS & NS & NS & 0.18 \\
\hline CLA trans 10 cis 12 & 0.06 & 0.06 & NS & NS & NS & 0.01 \\
\hline SFA & 69.46 & 69.99 & NS & NS & NS & 3.51 \\
\hline MUFA & 26.35 & 27.16 & NS & NS & NS & 2.19 \\
\hline PUFA & 2.32 & 3.23 & $* *$ & $* *$ & $* *$ & 0.54 \\
\hline$\sum$ CLA & 0.56 & 0.59 & NS & NS & NS & 0.12 \\
\hline PUFA omega 6 & 1.56 & 2.45 & $* *$ & $* *$ & $* *$ & 1.06 \\
\hline PUFA omega 3 & 0.20 & 0.19 & NS & NS & NS & 0.032 \\
\hline omega 6/omega 3 & 7.8 & 12.9 & $* *$ & $* *$ & $* *$ & 1.02 \\
\hline
\end{tabular}

SS, sorghum silage; CS, corn silage; SFA, saturated fatty acids; MUFA, monounsaturated fatty acids; PUFA, polyunsaturated fatty acids; CLAs, conjugated linoleic acids; ${ }^{* *}, p<0.01$; NS, Not Significant; SEM, standard error of mean. 


\subsection{Blood}

Blood chemistry parameters (Table 6) were in the normal range for the physiologic state of animals and no significant differences were detected between groups. Similarly, results concerning the oxidative status showed no d-ROMs either BAP differences.

Table 6. Blood chemistry parameters.

\begin{tabular}{cccccc}
\hline Blood Chemistry & Units & SS & CS & Group Effect & SEM \\
\hline BUN & $\mathrm{mg} / \mathrm{dL}$ & 20.87 & 23.12 & $\mathrm{NS}$ & 2.87 \\
CREA & $\mathrm{mg} / \mathrm{dL}$ & 0.831 & 0.806 & $\mathrm{NS}$ & 0.121 \\
GLU & $\mathrm{mg} / \mathrm{dL}$ & 50.18 & 47.78 & $\mathrm{NS}$ & 8.69 \\
$\mathrm{AST}$ & $\mathrm{U} / \mathrm{L}$ & 43.45 & 38.09 & $\mathrm{NS}$ & 6.13 \\
CHO & $\mathrm{mg} / \mathrm{dL}$ & 58.56 & 66.90 & $\mathrm{NS}$ & 13.48 \\
TRI & $\mathrm{mg} / \mathrm{dL}$ & 59.88 & 65.13 & $\mathrm{NS}$ & 9.09 \\
B-HBA & $\mathrm{mg} / \mathrm{dL}$ & 9.62 & 8.06 & $\mathrm{NS}$ & 1.02 \\
NEFA & $\mathrm{mg} / \mathrm{dL}$ & 6.73 & 5.82 & $\mathrm{NS}$ & 0.781 \\
d-ROMs & $\mathrm{UCARR}$ & 3224 & 3481 & $\mathrm{NS}$ & 1021 \\
BAP & $\mu \mathrm{mol} / \mathrm{L}$ & 38.9 & 44.6 & $\mathrm{NS}$ & 6.79 \\
\hline
\end{tabular}

SS, sorghum silage; CS, corn silage. NS, Not Significant. SEM, standard error of mean. BUN, blood urea nitrogen CREA, creatinine; GLU, glucose; AST, aspartate amino transferase; $\mathrm{CHO}$, cholesterol; TRI, triglycerides; B-HBA, $\beta$-hydroxybutyric acid; NEFA, non-esterified fatty acids; d-ROMS, reactive oxygen metabolites; BAP, biological antioxidant potential.

\section{Discussion}

The silages protein contents $(\mathrm{CP})$ were higher than those reported for both sorghum and corn silages by Cattani et al. [2], only for corn silage by Getachew et al. [16] and only for sorghum silage by Calabrò et al. [17]. On the contrary, CP content of sorghum silage in the present trial was similar to those found by Getachew et al. [16] and Grant et al. [18]. Sorghum silage showed higher NDF and lower ADL contents than corn silage, according to Calabrò et al. [17] while Cattani et al. [2] also reported ADL higher for sorghum than corn silage. This difference could be because BMR sorghum hybrids, such as the one used in the present trial, are characterized by the expression of a BMR gene associated with lower lignin concentration than comparable non-BMR hybrids [16].

Both silages used in this trial could be defined of good quality according to Grant et al. [18]. The fermentative parameters of corn silage were similar to those reported by Morand-Fehr and Tran [19], while Hassanat et al. [20] found lower lactic acid proportion $(38.6 \mathrm{~g} / \mathrm{kg} \mathrm{DM})$ and higher $\mathrm{NH}_{3}-\mathrm{N}$ content $(10.1 \mathrm{~g} / \mathrm{kg} \mathrm{DM})$. Our results concerning fermentative parameters of sorghum silage agree with those of Cattani et al. [2] while Grant et al. [21] reported higher concentration of acetic acid.

DMI was not different between groups, according to Cattani et al. [2], while milk yield was higher in buffalo cows fed sorghum silage. This result could be attributed to its lower ADL content compared to corn silage; in fact, according to Miron et al. [21], lower lignin content increased NDF digestibility. Moreover, Miron et al. [21] reported significantly higher $(p<0.05)$ NDF in vitro digestibility for sorghum than corn silage (60 vs. 56\%), despite their similar lignin contents (5.9 vs. 6.2\% DM, respectively for sorghum and corn silage). According to these authors, the higher levels of grain in corn silage can inhibit cellulolytic activity of rumen bacteria, thereby reducing the extent of corn NDF digestibility. In contrast, Barile et al. [22] found no differences in milk yield in buffalo cows fed with sorghum silage vs. corn silage diets. Several studies aimed to completely replace corn with sorghum silage in dairy cow's diet have been conducted with contrasting results. Indeed, milk yields were unaffected by treatment according to Miron et al. [21] and Khosravi et al. [23], while Colombini et al. [4] and Cattani et al. [2] reported higher milk yield when cows received the diet based on corn silage. This negative results for sorghum silage could be attributed to the variety of forage, in fact, Grant et al. [18] found negative influence of replacing corn with sorghum silage only when dairy cows were fed diet based on non-BMR sorghum while milk yield was unaffected when BMR was used. These authors reported 
also higher NDF digestibility for BMR than non-BMR sorghum silage. In the present trial, milk chemical characteristics were unaffected by treatment, according to Grant et al. [18]. Conversely, Miron et al. [21] and Cattani et al. [2] found that sorghum silage-based diet increased fat percentage compared to the corn silage diet. These authors attributed the effect to the greater intake of NDF when cows received the sorghum silage diet.

Replacing corn silage with sorghum silage in the diet of buffalo cows had no effect on milk saturated and monounsaturated fatty acids, whereas total polyunsaturated and particularly linoleic acid were greater with corn diet. Higher proportion of linoleic acid we have found also in corn silage than in sorghum silage, which instead showed higher percentage of alfa-linolenic acids. Cattani et al. [2] found either linoleic and alfa-linolenic acids higher in milk when cows were fed corn compared to sorghum silage; on the contrary Khosravi et al. [23] reported higher proportions of alfa-linolenic acid in milk of dairy cows fed sorghum silage diet. Both linoleic and alfa-linolenic acids are recognized as main precursors of milk CLA [24-26] which in the present trial was unaffected by the treatment in contrast with Cattani et al. [2] which reported higher total CLA when cows were fed sorghum silage. According to the results of these authors, also in the present trial replacing corn with sorghum silage determined improvements to the nutritional value of milk, particularly, a significant reduction of omega 6/omega 3 ratio was observed. These 2 classes of fatty acids have different physiological functions (pro- and anti-inflammatory activity for omega 6 and omega 3, respectively): lowering their ratio is considered optimal for human health [25].

Importantly, serum biochemistry showed that the experimental diet had no negative effects either at organ levels nor in terms of energy metabolism. All markers of health status showed no differences between groups, thus showing that the experimental diet did not affect cow metabolism. Also, the oxidative status did not change suggesting that the tested diet ensured a physiological Reactive Oxygen Species (ROS) production.

The concentrations of biochemical parameters in the serum of the animals were within the typical ranges reported for cattle [27] and the effects of experimental diet were similar. Absence of difference in blood parameters among the experimental cows was probably due to the similar diet nutritive values and DMI. The BUN is a well-known marker of protein status of an animal as well as of rumen performance [28], thus, these two aspects were not influenced by the sorghum diet. Blood glucose and NEFA are important markers of energy metabolism in dairy cows [29] and serum fatty acids negatively correlate with energy balance in dairy cows [30]. In our study, concentrations of NEFA, B-HBA, GLU, CHO and TRI in the two groups were within normal ranges [31], therefore, the lack of any differences between the diets was probably due to similar intakes and digestibility, and suggest that sorghum can be safely used. Such hypothesis is also confirmed by the results concerning the oxidative state of animals. The absence of differences in d-ROMs levels between groups shows that the SS diet did not increase oxidative stress and the antioxidant barrier (BAP) exerted the same protection of the CS diet against free radicals. This is important since BAP measures the plasma total antioxidant capability including both exogenous (ascorbate, tocopherols, carotenoids) and endogenous (superoxide dismutase, glutathione peroxidase, catalase) components that protect cells from the oxidant action of ROS [32]. In this view, evaluating the effects of a diet on oxidation status provides important information on animal health.

\section{Conclusions}

In conclusion, the present trial suggests that the complete replacing of corn silage with sorghum silage in the diet for dairy buffalo cows resulted in significantly higher milk yield without negative effects on animal health, milk protein, and fat concentrations. In addition, from a dietetic point of view, milk of buffalo cows fed sorghum silage seems to be more favorable. Indeed, even if the differences were only due to the decrease of linoleic acid, they determined significantly lower omega 6/omega 3 ratio recognized as having beneficial effects on human health. 
Author Contributions: Conceptualization R.T., P.L. and F.I.; Formal analysis R.T., N.M., V.M.M., M.G., M.F. and P.I. Methodology R.T., M.G., V.M.M., B.D.; Writing—original draft R.T., F.I., N.M. and P.L.; Writing-review \& editing F.I., P.L., M.F. and N.M. All authors have read and agreed to the published version of the manuscript.

Funding: This research received no external funding.

Institutional Review Board Statement: All the procedures used in the study were approved (protocol number: PG/0016571) by the Ethical Animal Care and Use Committee of the University of Naples Federico II in accordance with local and national law regulations and guidelines (Directive 2010/63/EU).

Informed Consent Statement: Not applicable.

Data Availability Statement: The data presented in this study are available on request from the corresponding author (nadia.musco@unina.it).

Acknowledgments: The authors would like to thank the Barchiesi Farm, Cassino, (FR) Italy.

Conflicts of Interest: The authors declare no conflict of interest.

\section{References}

1. ISMEA, XVIII Rapporto Ismea-Qualivita, l'indagine socio-economica del comparto italiano agroalimentare e vitivinicolo DOP IGP. 2020. Available online: https:/ / www.qualivita.it/rapporto-ismea-qualivita-2020/ (accessed on 3 June 2020).

2. Cattani, M.; Guzzo, N.; Mantovani, R.; Bailoni, L. Effects of total replacement of corn silage with sorghum silage on milk yield, composition, and quality. J. Anim. Sci. Biotechnol. 2017, 15, 8. [CrossRef]

3. Maunder, A.B. Sorghum Worldwide. In Sorghum and Millet Diseases; Leslie, J.F., Ed.; Iowa State Press: Iowa City, IA, USA, 2002; pp. 11-17.

4. Colombini, J.D.; Galassi, G.; Crovetto, G.M.; Rapetti, L. Milk production, nitrogen balance, and fiber digestibility prediction of corn, whole plant grain sorghum, and forage sorghum silages in the dairy cow. J. Dairy Sci. 2012, 95, 4457-4467. [CrossRef] [PubMed]

5. Cavaliere, G.; Trinchese, G.; Musco, N.; Infascelli, F.; De Filippo, C.; Mastellone, V.; Morittu, V.M.; Lombardi, P.; Tudisco, R.; Grossi, M.; et al. Milk from cows fed a diet with a high forage: Concentrate ratio improves inflammatory state, oxidative stress, and mitochondrial function in rats. J. Dairy Sci. 2018, 101, 1843-1851. [CrossRef]

6. Trinchese, G.; Cavaliere, G.; Penna, E.; De Filippo, C.; Cimmino, F.; Catapano, A.; Musco, N.; Tudisco, R.; Lombardi, P.; Infascelli, F.; et al. Milk from cow fed with high forage/concentrate ratio diet: Beneficial effect on rat skeletal muscle inflammatory state and oxidative stress through modulation of mitochondrial functions and AMPK activity. Front. Phys. 2019, 9, 1969. [CrossRef] [PubMed]

7. Gammone, M.A.; Riccioni, G.; Parrinello, G.; D'Orazio, N. Omega-3 Polyunsaturated Fatty Acids: Benefits and Endpoints in Sport. Nutrients 2018, 11, 46. [CrossRef]

8. Calabrò, S.; Cutrignelli, M.I.; Piccolo, G.; Bovera, F.; Zicarelli, F.; Gazaneo, M.P.; Infascelli, F. In vitro fermentation kinetics of fresh and dried silage. Anim. Feed Sci. Tech. 2005, 123-124, 129-137. [CrossRef]

9. AOAC. Official Methods of Analysis, 19th ed.; Association of Official Analytical Chemists: Arlington, VA, USA, 2012.

10. Van Soest, P.J.; Robertson, J.B.; Lewis, B.A. Methods for dietary fiber, neutral detergent fiber, and nonstarch polysaccharides in relation to animal nutrition. J. Dairy Sci. 1991, 74, 3583-3598. [CrossRef]

11. Sauvant, D.; Noziere, P. La quantification des principaux phénomènes digestifs chez les ruminants: Les relations utilisées pour rénover les systèmes d'unités d'alimentation énergétique et protéique. Prod. Anim. 2013, 26, 327-346. [CrossRef]

12. Folch, J.; Lees, M.; Sloone Stanley, G.H. A simple method for the determination and purification of total lipids from animal tissues J. Biol. Chem. 1957, 226, 497-509. [CrossRef]

13. Hara, A.; Radin, N.S. Lipid extraction of tissues with a low-toxicity solvent. Anal. Biochem. 1978, 90, 420-426. [CrossRef]

14. Tudisco, R.; Grossi, M.; Calabrò, S.; Cutrignelli, M.I.; Musco, N.; Addi, L.; Infascelli, F. Influence of pasture on goat milk fatty acids and Stearoyl-CoA desaturase gene expression in milk somatic cells. Small Rum Res. 2014, 122, 38-43. [CrossRef]

15. Bittante, G.; Andrighetto, I.; Ramanzin, M. Fondamenti di Zootecnica; Liviana Editrice: Padova, Italy, 1990.

16. Getachew, G.; Putnam, D.H.; De Ben, C.M.; De Peters, E.J. Potential of Sorghum as an Alternative to Corn Forage. Am. J. Plant Sci. 2016, 7, 1106-1121. [CrossRef]

17. Calabrò, S.; Tudisco, R.; Grossi, M.; Gonzales, O.J.; Caiazzo, C.; Guglielmelli, A.; Piccolo, V.; Infascelli, F.; Cutrignelli, M.I. Nutritive value of silages utilized in buffalo nutrition. Rev. Vet. 2010, 21, 683-685.

18. Grant, R.J.; Haddad, S.G.; Moore, K.J.; Pedersen, J.F. Brown midrib sorghum silage for midlactation dairy cows. J. Dairy Sci. 1995, 78, 1070-1980. [CrossRef]

19. Morand-Fehr, P.; Tran, G. La fraction lipidique des aliments et les corps gras utilisés en alimentation animale. INRA Prod. Anim. 2001, 14, 285-302. [CrossRef] 
20. Hassanat, F.; Gervais, R.; Julien, C.; Massé, D.I.; Lettat, A.; Chouinard, P.Y.; Petit, H.V.; Benchaar, C. Replacing alfalfa silage with corn silage in dairy cow diets: Effects on enteric methane production, ruminal fermentation, digestion, $\mathrm{N}$ balance, and milk production. J. Dairy Sci. 2013, 96, 4553-4567. [CrossRef]

21. Miron, J.; Zuckerman, E.; Adin, G.; Solomon, R.; Shoshani, E.; Nikbachat, M.; Yosef, E.; Zenou, A.; Weinberg, Z.G.; Chena, Y.; et al. Comparison of two forage sorghum varieties with corn and the effect of feeding their silages on eating behaviour and lactation performance of dairy cows. Anim. Feed Sci. Tech. 2007, 139, 23-39. [CrossRef]

22. Barile, V.L.; Tripaldi, C.; Pizzoferrato, L.; Pacelli, C.; Palocci, G.; Allegrini, S.; Maschio, M.; Mattera, M.; Manzi, P.; Borghese, A. Effects of different diets on milk yield and quality of lactating buffaloes: Maize versus sorghum silage. Italian J. Anim. Sci. 2007, 6, 520-523. [CrossRef]

23. Khosravi, M.; Rouzbehan, Y.; Rezaei, M.; Rezaei, J. Total replacement of corn silage with sorghum silage improves milk fatty acid profile and antioxidant capacity of Holstein dairy cows. J. Dairy Sci. 2018, 101, 10953-10961. [CrossRef]

24. Kim, Y.J.; Liu, R.H.; Bond, D.R.; Russell, J.B. Effect of linoleic acid concentration on conjugated linoleic acid by Butyrivibrio fibrisolvens A38. Appl. Environ. Microbiol. 2000, 66, 5226-5230. [CrossRef]

25. Simopoulos, A.P. The importance of the ratio of omega-6/ omega-3 essential fatty acids. Biomed. Pharmacother. 2002, 56, 365-379. [CrossRef]

26. Tudisco, R.; Chiofalo, B.; Lo Presti, V.; Morittu, V.M.; Moniello, G.; Grossi, M.; Musco, N.; Grazioli, R.; Mastellone, V.; Lombardi, P.; et al. Influence of feeding linseed on SCD activity in grazing goat mammary glands. Animals 2019, 9, 786. [CrossRef] [PubMed]

27. Radostits, O.M.; Gay, C.C.; Hinchcliff, K.W.; Constable, P.D. Diseases of the abomasum. In Veterinary Medicine: A Textbook of the Diseases of Cattle, Horses, Sheep, Pigs and Goats, 10th ed.; Radostits, O.M., Gay, C.C., Hinchcliff, K.W., Constable, P.D., Eds.; Elsevier: Philadelphia, PA, USA, 2007; pp. 353-374.

28. Hess, H.S.; Lascano, C.E.; Flórez, H. Blood and Milk Urea Nitrogen as a Tool to Monitor the Protein Nutrition of Cattle under Tropical Conditions; Institute of Animal Sciences, Animal Nutrition ETH: Zurich, Switzerland, 2000.

29. Yang, Y.; Nan, Z.; Zhao, X.; Zhang, Y.; Han, R.; Yang, J.; Zhao, S.; Li, S.; Guo, T.; Zang, C.; et al. Metabolomic biomarkers identify differences in milk produced by Holstein cows and other minor dairy animals. J. Proteom. 2016, 136, 174-182. [CrossRef] [PubMed]

30. Butler, S.T.; Pelton, S.H.; Butler, W.R. Energy Balance, Metabolic Status, and the First Postpartum Ovarian Follicle Wave in Cows Administered Propylene Glycol. J. Dairy Sci. 2006, 89, 2938-2951. [CrossRef]

31. Drackley, J.M.; Overton, T.R.; Douglas, N. Adaptations of glucose and log-chain fatty acid metabolism in liver of dairy cows during the periparturient period. J. Dairy Sci. 2001, 84, E100-E112. [CrossRef]

32. Sciorsci, R.L.; Galgano, M.; Mutinati, M.; Rizzo, A. Oxidative state in the estrus cycle of the buffaloes: A preliminary study. Trop. Anim. Health Prod. 2020, 52, 1331-1334. [CrossRef] 